\title{
Role of 3D Ultrasound for Assessment of Fetal Lungs
}

\author{
LOBNA S. IBRAHEM, M.Sc.; SAFAA K. MOHAMED, M.D. and NERMEEN N. KERIAKOS, M.D. \\ The Department of Radiodiagnosis, Faculty of Medicine, Ain Shams University
}

\begin{abstract}
Background: Fetal lung maturity is vital to the survival rate of neonates, and is a determinant of extra uterine life. Neonatal respiratory distress syndrome and associated complications account for $28 \%$ of neonatal deaths. Although the wide use of glucocorticoids has decreased the incidence of Neonatal respiratory distress syndrome, approximately $10 \%$ of neonates still develop the syndrome.
\end{abstract}

Aim of Study: To study the role of 3D ultrasound for assessment of fetal lungs.

Patients and Methods: A total of 50 pregnant women 3440 weeks gestation after a complication-free normal course of pregnancy were enrolled in the study. They were classified into 2 groups as follows: 1 . Group A: $(n=25)$ women $34-37$ weeks gestation. 2. Group B: $(n=25)$ women $37-40$ weeks gestation. All the included women were subjected to: Full history taken. Ultrasound examination to confirm GA, assess Amniotic Fluid Index (AFI) and to exclude fetal anomalies. $3 \mathrm{D}$ ultrasound was carried out to asses fetal lung volume. After child birth, APGAR score at (1,5 and 10min) was assessed together with occurrence of RDS and the further need for neonatal ICU admission and respiratory support measurements.

Results: The mean value of fetal lung volume was significantly increased in term group (52.96 \pm 4.91$)$ when compared to preterm group $(44.08 \pm 6.43)(p=0.001)$. In the term group the percentage of neonates which did not experience Respiratory Distress Syndrome (RDS) was $60 \%$ compared to $24 \%$ in the preterm group $(p=0.001)$. In the preterm group the percentage of admitted neonates in the Intensive Care Unit (ICU) was statistically increased (68\%) when compared to the term group $(54 \%)(p=0.047)$. The percentage of women in the preterm group received prenatal steroids $36 \%$ was statistically higher than those in the term group 24\% $(p=0.047)$. In the present study, fetal lung volume was positively correlating with gestational age $(r=0.531 ; p$-value $=0.001)$. In the present study, in the preterm group RDS was negatively correlated with steroids $(r=-0.304 ; p$-value $=0.032)$.

Conclusion: Ultrasound indices, including fetal lung volume may serve as useful alternatives to amniotic fluid phospholipids in analyzing fetal lung maturity. Fetal lung volume might be an accurate non-invasive predictor for the occurrence of neonatal RDS among preterm fetuses in whom

Correspondence to: Dr. Lobna S. Ibrahem,

E-Mail: d.lobnasileem@gmail.com the risk of RDS development deserve fetal lung maturity testing.

Key Words: 3D ultrasound-Fetal lungs.

\section{Introduction}

THE maturation of fetal pulmonary system is a complex process entailing cellular, physiological, and biological interactions that usually occurs late in gestation being one of the last maturing fetal systems [1].

Therefore, respiratory distress is commonly encountered among premature babies immediately after birth resulting in significant neonatal morbidity or mortality. It has been established to correlate with structural and functional lung immaturity. It is described as respiratory distress in infants that sets in within a few hours of parturition. The incidence of RDS is inversely proportional to gestational length and has been estimated to range from $30 \%$ below gestational week 28 to $5 \%$ in neonates born in a gestational week above 34 [2]

Three types of tests are traditionally used to assess the degree of Fetal Lung Maturity (FLM) namely; the biochemical testing for surfactant components (e.g. Lecithin/sphingomyelin ratio), biophysical testing for surfactant functionality (e.g. Foam stability index) or physical testing of the amniotic fluid opacity (e.g. lamellar body counts [3].

All these tests involve the use of amniotic fluid (as it communicates directly with lung fluid), therefore, invasively and indirectly evaluate the probability of lung maturity. Moreover, they predict lung maturity more accurately than immaturity. Tests that directly assess fetal lung function are yet not available [4].

Ultrasound cannot measure biochemical changes in the growing lung or histological changes but 
it is reasonable to assume that both morphological and biochemical changes alter the propagation properties in the fetal lung. The possibilities of using ultrasound as a non-invasive method for assessment of fetal lung maturity have been greatly explored over the last 30 years [5] .

Three-dimensional sonographic measurements are shown to be helpful in assessing the fetal lung volume. Fetal lung volumetry with 3D sonography can be regarded as a good alternative to MRI [6] .

\section{Aim of the work:}

The purpose of this study is to correlate lung parameters using three dimensional ultrasound (3D US) with lung maturity assessed by postnatal outcome, and to develop reference cutoff value for these parameters (mean FLV) as measure that could be used to predict the development of neonatal RDS.

\section{Patients and Methods}

This study cross section study was conducted on fifty pregnant females aged 18 years up to 40 years between 34 to 40 weeks gestational age of pregnancy at Ain Shams University Hospitals, Egypt, between March 2019 and August 2019.

The study included female participants from 18 years up to 40 years old, with singleton pregnancy with no history of chronic hypertension or diabetes (type I or type II) before pregnancy. While patients who refused to participate in the study and fetal malformation were excluded from the study.

The participants were divided into two groups; Group A (women pregnant 34-37 weeks gestation) and Group B (women pregnant 37 to 40-week gestation. Gestational Age (GA) was established by menstrual dates, which was confirmed by obstetric ultrasound.

For both groups, full history was taken. Ultrasound was done to confirm GA, assess Amniotic Fluid Index (AFI) and to exclude fetal anomalies. GE Voluson S6 ultrasound machine, equipped with 3D probe RAB2-6-RS $2-5 \mathrm{MHz}$ was carried out to assess fetal lung volume.

All participants signed an informed consent after explaining the objective of the study to them.

The methods and procedures of the present study are in agreement with the Heliniski Declaratin for Ethical Medical research.
The protocol was revised by the Ethical committee of Obstetrics and Gynecology Department and/or the Ethical Committee of Faculty of Medicine, Ain Shams University.

Women had adequate time to consider enrollment and discuss options with their physician prior to cesarean section. All eligible patients who present to labor and delivery for cesarean section were examined upon presentation. After inclusion criteria have been met, the patient was approached for consent to participate in the study. Patients were given study information and the consent form to review. Consent was documented by the patient's signature indicating understanding and agreement to participate in the study.

The participating women have the right to withdraw from the study without being adversely impacted regarding the medical service she should receive.

Statistical analysis comparisons among patients underwent cleaning uterine cavities with a dry laparotomy sponge after delivery of the placenta and patients who didn't undergo cleaning uterine cavities were done using the Student's $t$-test for continuous variables and Pearson's chi square test for categorical variables.

Statistical package: Data entry and statistical analysis were done using Statistical Package for Social Science (SPSS) version 21.0.

\section{Statistical analysis:}

Data collected throughout history, basic clinical examination, laboratory investigations and outcome measures coded, entered and analyzed using Microsoft Excel software. The data collected were tabulated and analyzed by SPSS (statistical package for social science) version 25 (Armonk, NY: IBM Corp) on IBM compatible computer. The data was tested for normality using Kolmogorov-Smirnov test, Shapiro-Wilk tests. Two types of statistics were done:

\section{Descriptive statistics:}

According to the type of data qualitative represent as number and percentage, quantitative continues group represent by mean $\pm \mathrm{SD}$ (for parametric data) median and inter-quartile range (for nonparametric data).

Analytic statistics:

Chi-square test $\left(\chi^{2}\right)$ : Was used to study comparison and association between two qualitative variables. Student $t$-test: Was used for comparison between two groups having quantitative variables 
with normal distribution (for parametric data). Mann-Whitney U-Test: Is a test of significance used for comparison between two groups having quantitative variables without normal distribution (for non-parametric data), correlation by Spearman's correlation. A $p$-value of $<0.05$ was considered statistically significant.

\section{Results}

Table (1): Demographic data of the two studied groups.

\begin{tabular}{llll}
\hline & \multicolumn{2}{c}{ Groups } & $p$ - \\
\cline { 2 - 3 } & $\begin{array}{c}\text { Group A (n=25) } \\
\text { (Preterm Group) }\end{array}$ & $\begin{array}{c}\text { Group B (n=25) } \\
\text { (Term Group) }\end{array}$ & \\
\hline $\begin{array}{llll}\text { Age (years): } \\
\text { Range }\end{array}$ & $18-33$ & $18-33$ & 0.974 \\
Mean \pm SD & $23.96 \pm 4.21$ & $23.92 \pm 4.415$ & \\
GA (weeks): & & & $0.001 * *$ \\
Range & $34-37$ & $38-40$ & \\
Mean \pm SD & $34.88 \pm 0.781$ & $38.92 \pm 0.759$ & \\
\hline
\end{tabular}

The (Table 1) shows preterm group $(\mathrm{n}=25)$ where the pregnant women at 34-37 weeks of gestation, their age ranged from 18 to 33 years with mean age was equal to 23.96 years $( \pm S D$ $=4.21)$ and term group $(n=25)$ where the pregnant women at 37-40 weeks gestation, their age ranged from 18 to 33 years with mean age was equal to 23.92 years $( \pm \mathrm{SD}=4.41)$, There was no statistical significant difference between the mean age in the two studied groups.

Table (2): Comparison between mode of delivery in the two studied groups.

\begin{tabular}{lccccccc}
\hline & \multicolumn{6}{c}{ Groups } & \\
\cline { 2 - 6 } $\begin{array}{l}\text { Mode of } \\
\text { delivery }\end{array}$ & $\begin{array}{c}\text { Group A } \\
(\mathrm{n}=25) \\
(\text { Preterm } \\
\text { Group) }\end{array}$ & $\begin{array}{c}\text { Group B } \\
(\mathrm{n}=25) \\
(\text { Term } \\
\text { Group })\end{array}$ & Total & $\begin{array}{c}p \text { - } \\
\text { value }\end{array}$ \\
\cline { 2 - 6 } & $\mathrm{N}$ & $\%$ & $\mathrm{~N}$ & $\%$ & $\mathrm{~N}$ & $\%$ & \\
\hline Normal & 10 & 40 & 13 & 52 & 23 & 46 & 0.395 \\
CS & 15 & 60 & 12 & 48 & 27 & 54 & \\
\hline Total & 25 & 100 & 25 & 100 & 50 & 100 & \\
\hline
\end{tabular}

Table (3): Comparison between fetal lung volume in the two studied groups.

\begin{tabular}{lccc}
\hline \multirow{2}{*}{$\begin{array}{l}\text { Fetal lung } \\
\text { volume }\end{array}$} & \multicolumn{2}{c}{ Groups } & $\begin{array}{c}p \text { - } \\
\text { value }\end{array}$ \\
\cline { 2 - 3 } & $\begin{array}{c}\text { Group A (n=25) } \\
\text { (Preterm Group) }\end{array}$ & $\begin{array}{c}\text { Group B (n=25) } \\
\text { (Term Group) }\end{array}$ \\
\hline Range & $35-55$ & $44-61$ & $0.001^{* *}$ \\
Mean \pm SD & $44.08 \pm 6.43$ & $52.96 \pm 4.91$ & \\
\hline
\end{tabular}

The (Table 2) shows that in preterm group, 15 women out of 25 had a cesarean delivery $60 \%$, while in term group 12 women out of 25 had a cesarean delivery $48 \%$ with no statistically significant difference $(p=0.395)$.

This (Table 3) shows that, the mean value of fetal lung volume had statistically significant increase in term group $(52.96 \pm 4.91)$ when compared to preterm group $(44.08 \pm 6.43)(p<0.001)$.

Table (4): APGR score measured at different time of measurements in the two studied groups.

\begin{tabular}{|c|c|c|c|c|c|}
\hline \multirow{3}{*}{ APGR score } & \multicolumn{4}{|c|}{ Groups } & \multirow{3}{*}{$\begin{array}{c}p- \\
\text { value }\end{array}$} \\
\hline & \multicolumn{2}{|c|}{$\begin{array}{c}\text { Group A } \\
(\mathrm{n}=25) \\
\text { (Preterm } \\
\text { Group) }\end{array}$} & \multicolumn{2}{|c|}{$\begin{array}{c}\text { Group B } \\
(\mathrm{n}=25) \\
\text { (Term } \\
\text { Group) }\end{array}$} & \\
\hline & $\mathrm{N}$ & $\%$ & $\mathrm{~N}$ & $\%$ & \\
\hline \multicolumn{6}{|l|}{ APGR1 minute: } \\
\hline Normal foal & 1 & 4.0 & 23 & 92.0 & $0.001 * *$ \\
\hline Intervention & 15 & 60.0 & 2 & 8.0 & \\
\hline Life threatening & 9 & 36.0 & 0 & 0.0 & \\
\hline \multicolumn{6}{|l|}{ APGR 5 minutes: } \\
\hline Normal foal & 5 & 20.0 & 23 & 92.0 & $0.001 * *$ \\
\hline Intervention & 20 & 80.0 & 2 & 8.0 & \\
\hline \multicolumn{6}{|l|}{ APGR 10 minutes: } \\
\hline Normal foal & 7 & 28.0 & 23 & 92.0 & $0.001 * *$ \\
\hline Intervention & 18 & 72.0 & 2 & 8.0 & \\
\hline
\end{tabular}

This table shows that the percentage of neonates who had life threatening APGR score measured at 1 minute in preterm group was $36 \%$, while in term group was zero which statistically significant increase in preterm group $(p=0.001)$. APGR score measured at both 5 and 10 minutes recorded that the percentage of neonates who needed intervention in preterm group was $80 \%$ \& $72 \%$ and in term group $8.0 \%$ \& $8.0 \%$ respectively indicating statistically significant increase in preterm group $(p=$ $0.001 \& 0.001$, respectively).

Table (5): Respiratory distress syndrome in the two studied groups.

\begin{tabular}{|c|c|c|c|c|c|c|c|}
\hline \multirow{3}{*}{ RDS } & \multicolumn{6}{|c|}{ Groups } & \multirow{3}{*}{$\begin{array}{c}p- \\
\text { value }\end{array}$} \\
\hline & \multicolumn{2}{|c|}{$\begin{array}{c}\text { Group A } \\
(\mathrm{n}=25) \\
\text { (Preterm } \\
\text { Group) }\end{array}$} & \multicolumn{2}{|c|}{$\begin{array}{c}\text { Group B } \\
(\mathrm{n}=25) \\
\text { (Term } \\
\text { Group) }\end{array}$} & \multicolumn{2}{|c|}{ Total } & \\
\hline & $N$ & $\%$ & $N$ & $\%$ & $\mathrm{~N}$ & $\%$ & \\
\hline No RDS & 10 & 40 & 23 & 92 & 33 & 66 & $0.001 *$ \\
\hline RDS & 15 & 60 & 2 & 8 & 17 & 34 & \\
\hline Total & 25 & 100 & 25 & 100 & 50 & 100 & \\
\hline
\end{tabular}


This table shows that in the term group the percentage of neonates which did not experience Respiratory Distress Syndrome (RDS) was 92\% which was significantly higher than the $40 \%$ in the preterm group $(p=0.001)$.

Table (6): Neonatal Intensive Care Unit (ICU) admission in the two studied groups.

\begin{tabular}{|c|c|c|c|c|c|c|}
\hline \multirow{3}{*}{$\begin{array}{l}\text { ICU } \\
\text { admission }\end{array}$} & \multicolumn{5}{|c|}{ Groups } & \multirow{3}{*}{$\begin{array}{c}p- \\
\text { value }\end{array}$} \\
\hline & $\begin{array}{r}\text { Grol } \\
(\mathrm{n}= \\
\text { (Pre } \\
\text { Gro }\end{array}$ & $\begin{array}{l}\text { up A } \\
25) \\
\text { term } \\
\text { up) }\end{array}$ & $\begin{array}{r}\text { Gro } \\
\text { (n } \\
(\mathrm{T} \\
\mathrm{Gr}\end{array}$ & $\begin{array}{l}\text { oup B } \\
=25 \text { ) } \\
\text { oup) }\end{array}$ & Total & \\
\hline & $N$ & $\%$ & $N$ & $\%$ & $\mathrm{~N} \%$ & \\
\hline No admission & 10 & 32 & 25 & 100 & 46 & $0.047 *$ \\
\hline Admission & 15 & 68 & 0 & 0 & $27 \quad 54$ & \\
\hline Total & 25 & 100 & 25 & 100 & 50100 & \\
\hline
\end{tabular}

This table shows that in the preterm group the percentage of admitted neonates in the Intensive Care Unit (ICU) was statistically higher (68\%) when compared to the term group ( $0 \%)(p=0.047)$.

Table (7): Prenatal steroids administration in the two studied groups.

\begin{tabular}{|c|c|c|c|c|c|c|c|}
\hline \multirow{3}{*}{$\begin{array}{l}\text { Prenatal } \\
\text { Steroids } \\
\text { administration }\end{array}$} & \multicolumn{6}{|c|}{ Groups } & \multirow{3}{*}{$\begin{array}{c}p- \\
\text { value }\end{array}$} \\
\hline & $\begin{array}{l}\text { Gro } \\
(\mathrm{n}= \\
(\text { Pre } \\
\text { Gro }\end{array}$ & $\begin{array}{l}\text { up A } \\
\text { 25) } \\
\text { term } \\
\text { up) }\end{array}$ & & $\begin{array}{l}\text { up B } \\
=25 \text { ) } \\
\text { erm } \\
\text { oup) }\end{array}$ & \multicolumn{2}{|c|}{ Total } & \\
\hline & $N$ & $\%$ & $N$ & $\%$ & $\mathbf{N}$ & $\%$ & \\
\hline No & 16 & 64 & 22 & 88 & 38 & 76 & $0.047^{*}$ \\
\hline Yes & 9 & 36 & 3 & 12 & 12 & 24 & \\
\hline Total & 25 & 100 & 25 & 100 & 50 & 100 & \\
\hline
\end{tabular}

This table shows that, the percentage of women who were administrated prenatal steroids in the preterm group $36 \%$, was statistically higher than those in the term group $12 \%$, whereas $(p=0.047)$.

Table (8): Correlation between fetal lung volume and different studied parameters in both groups.

\begin{tabular}{llc}
\hline \multirow{2}{*}{ Parameters } & \multicolumn{2}{c}{ Fetal Lung Volume (FLV) } \\
\cline { 2 - 3 } & \multicolumn{1}{c}{$r$} & $p$-value \\
\hline Gestational age & 0.531 & $0.001^{*}$ \\
APGR 1 minute & -0.687 & $0.001^{*}$ \\
APGR 5 minutes & -0.692 & $0.010^{* *}$ \\
APGR 10 minutes & -0.693 & $0.001^{* *}$ \\
RDS & -0.768 & $0.001^{* *}$ \\
NICU admission & -0.766 & $0.001^{* *}$ \\
Steroids & 0.244 & 0.088 \\
\hline
\end{tabular}

Fetal Lung Volume (FLV) was positively correlated with gestational age $(r=0.531 ; p$-value $=$ $0.001)$.
At the same time, fetal lung volume was negatively correlated with APGR score at 1 minute $(r=0.687 ; p$-value $=0.001), 5$ minutes $(r=0.692$; $p$-value $=0.001)$, and 10 minutes $(r=-0.693 ; p$-value $=0.001), \operatorname{RDS}(r=-0.768 ; p$-value $=0.001)$ and NICU admission $(r=0.766 ; p$-value $=0.001)$.

On the other hand, the fetal lung volume was no statistically correlated with prenatal administration of steroids $(r=0.244 ; p=0.088$ ).

Table (9): Correlation between RDS and steroids in both groups.

\begin{tabular}{lcc}
\hline Parameters & \multicolumn{2}{l}{ Respiratory distress syndrome (RDS) } \\
\cline { 2 - 3 } & $r$ & $p$-value \\
\hline Steroids & -0.304 & $0.032 *$ \\
\hline
\end{tabular}

This table shows that RDS was negatively correlated with steroids ( $r=-0.304 ; p$-value $=0.032$ ).

Table (10): The diagnostic indices (sensitivity, specificity, positive predictive and negative predictive values) of FLV in the studied patients.

\begin{tabular}{lcccc}
\hline Cutoff & Sensitivity & Specificity & PPV & NPV \\
\hline$>49.50^{*}$ & 87.80 & 88.20 & 92.90 & 68.2 \\
\hline
\end{tabular}

Receiver Operating Curve (ROC) was used to determine the cutoff value of FLV in determining neonatal respiratory function outcome. Our ROC results revealed that the FLV cutoff value is greater than 49.50 and the area under the ROC curve is equal to 0.936 which indicating that it is an excellent predictor for neonatal respiratory function outcome. The sensitivity, specificity, positive predictive and negative predictive values of FLV were $87.80 \%, 88.20 \%, 92.90 \%$ and $68.2 \%$.

\section{- Clinical background:}

Female patient 28 years old (pregnant \pm 35 weeks).

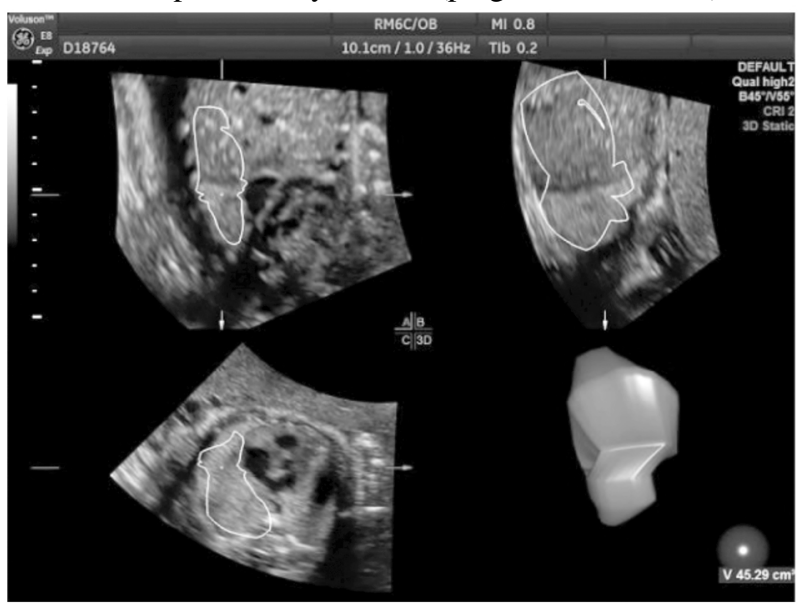

Fig. (1): 3D ultrasound using VOCAL method shows fetal right lung volume measuring $45.29 \mathrm{~cm}$ (group A - a case pregnant \pm 35 weeks). 
Female patient 30 years old (pregnant \pm 37 weeks).

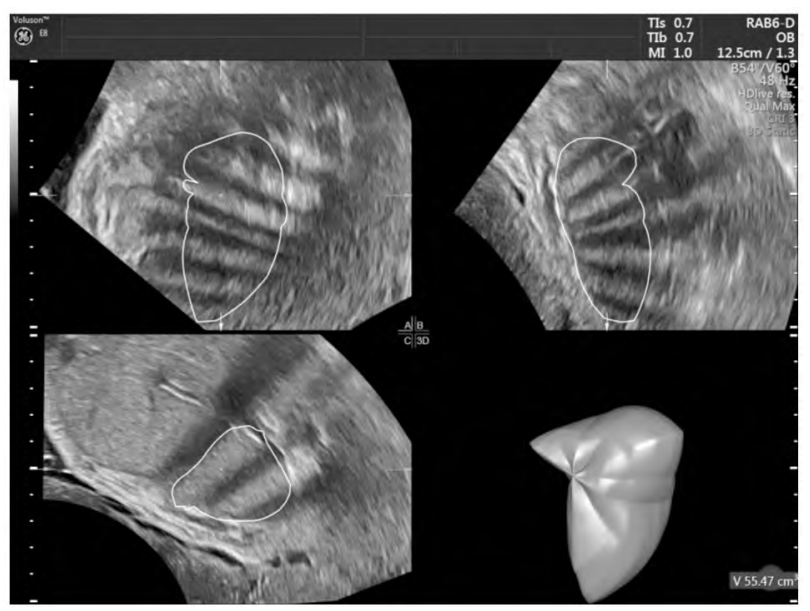

Fig. (2): 3D ultrasound using VOCAL method shows fetal right lung volume measuring $55.47 \mathrm{~cm}$ (group B - a case pregnant \pm 37 weeks).

\section{Discussion}

Neonatal respiratory morbidity due to either respiratory distress syndrome or transient tachypnea of the newborn is the most common complication in infants born preterm and early term $(<39$ weeks $)$ [7]

Assessment of fetal lung maturity for the prediction of Neonatal respiratory morbidity may be relevant, particularly after 34 weeks of gestation, when the risk of Neonatal respiratory morbidity ranges from $5 \%$ to $20 \%$, to better assess the risk/ benefit ratio of elective delivery in late pregnancy complications [8] and/or with the use of corticosteroids (Gyamfi-Bannerman et al., 2016).

RDS is the most common cause of neonatal respiratory morbidity. The underlying mechanism has been correlated to functional or/and structural lung immaturity [2].

Accurate predelivery assessment of fetal lung maturity, especially in high-risk pregnancy, is critical to improving neonatal survival rate [9]

The evaluation of the risk of Neonatal respiratory morbidity relies on the study of different components of the amniotic fluid that requires an amniocentesis, which is an invasive method and carries risks [10].

There is no simple, non-invasive method for assessing fetal pulmonary maturity. Because the duration of respiration and of inspiration is variable due to internal and external simulations, the spectrum of breathing-related movement is variable and difficult to calculate. Therefore, a reliable and simple estimation method of fetal lung maturity is needed [9]

In the current study, the mean value of fetal lung volume was significantly increased in term group $(52.96 \pm 4.91)$ when compared to preterm group $(44.08 \pm 6.43)(p=0.001)$. This agrees with Laban and his colleagues, in a cross-sectional study, women aged 20-35 years were enrolled and admitted to a tertiary hospital in Cairo, Egypt, for elective repeat cesarean at 37-40 weeks of pregnancy between January 1, 2012, and July 31, 2013, found that; healthy neonates, compared with neonates with RDS, had significantly higher FLVs $(p<0.001)$ [11]

Previous studies have shown that fetal heart movements can be a main limiting factor for 3D ultrasonographic lung volume measurement, [13,14], and have suggested that a system combining fetal electrocardiography with $3 \mathrm{D}$ ultrasonography is required [12].

Kalache and his colleagues used relatively fast volume acquisition rates so that fetal heart contractions did not appear to prevent lung measurements by VOCAL, despite the fact that the six measured slices included outer cardiac borders [15].

As pointed out by Peralta and his colleagues the advantage of the VOCAL technique is that the lower parts of the lung that extend below the dome of the diaphragm can be included and the contour of the lung in each plane can be modified to ensure a more accurate lung volume measurement [16]

In the term group the percentage of neonates which did not experience Respiratory Distress Syndrome (RDS) was $60 \%$ compared to $24 \%$ in the preterm group $(p=0.001)$. Kantake and his coworkers, in a prospective cohort study, found that $52.6 \%$ of the preterm group had RDS while no one in the term group experience respiratory distress syndrome [17]

In the preterm group the percentage of admitted neonates in the Intensive Care Unit (ICU) was statistically increased $(68 \%)$ when compared to the term group (54\%) $(p=0.047)$.

Our result showed that, the percentage of women in the preterm group received prenatal steroids $36 \%$ was statistically higher than those in the term group 24\% ( $p=0.047)$. This is in accordance with Kantake and his co-workers $50 \%$ of women in the preterm group received prenatal steroids while $0 \%$ of those in the term group received prenatal steroids [17] . 
In the present study, fetal lung volume was positively correlating with gestational age $(r=0.531$; $p$-value $=0.001)$. As the image quality more influenced by the shadowing of the spine and ribs especially after 34 weeks with inaccurate measurement of the lung volume [18] and this is in agreement with the study of Osada and his colleagues which included one hundred twenty-five healthy neonates with birth weights.

In the present study, in the preterm group RDS was negatively correlated with steroids ( $r=-0.304$; $p$-value $=0.032$ ).

In the present study, Receiver Operating Curve (ROC) was used to determine the cutoff value of FLV in determining neonatal respiratory function outcome. Our ROC results revealed that the FLV cutoff value is greater than 49.50 and the area under the ROC curve is equal to 0.936 which indicating that it is an excellent predictor for neonatal respiratory function outcome. The sensitivity, specificity, positive predictive and negative predictive values of FLV were $87.80 \%, 88.20 \%$, 92.90\% and $68.2 \%$ respectively.

Laban and his colleagues found that neonatal RDS is less likely with FLV of at least $32 \mathrm{~cm}^{3}$ [11]

Prendergast and his colleagues reported that 3D FLVs might be useful in predicting neonatal respiratory outcome among fetuses with abnormal lung growth (with congenital diaphragmatic hernia $\&$ with anterior wall defects) [19]

Wang and his colleagues reported that; based on comparison with the amniotic fluid phospholipids analysis, FLV $>50 \mathrm{~mL}$ was considered to indicate fetal lung maturity with high sensitivity and specificity [9].

\section{Conclusion:}

To date, no unified sonographic standard of fetal lung maturity exists, due to the variability of fetal lung echoes during pregnancy and complications associated with the fetal position, pregnant mother, or equipment. Ultrasound indices, including fetal lung volume may serve as useful alternatives to amniotic fluid phospholipids in analyzing fetal lung maturity. Fetal lung volume might be an accurate non-invasive predictor for the occurrence of neonatal RDS among preterm fetuses in whom the risk of RDS development deserve fetal lung maturity testing.

\section{References}

1- SENTHILKUMAR V. and EZHILARASI M.: An investigation of lung maturity analysis through kernelized fuzzy rough set feature partitioning. Aust. J. Basic. Appl. Sci., 9: 241-9, 2015.
2- HERMANSEN C.L. and LORAH K.N.: Respiratory distress in the newborn. Am. Fam. Physician, 76 (7): $987-$ 94, 2007.

3- VARNER S., SHERMAN C., LEWIS D., et al.: Amniocentesis for fetal lung maturity: Will it become obsolete? Rev. Obstet. Gynecol., 6: 126-34, 2013.

4- MAGED A., YOUSSEF G., HUSSIEN A., et al.: The role of three-dimensional ultrasonography fetal lung volume measurement in the prediction of neonatal respiratory function outcome. The Journal of maternal-fetal \& neonatal medicine, 1-6, 2017.

5- PALACIO M., COBO T., MARTÍNEZ-TERRÓN M., et al.: Performance of an automatic quantitative ultrasound analysis of the fetal lung to predict fetal lung maturity. Am. J. Obstet. Gynecol., 207 (6): e1-5, 2012.

6- KEHL S., KALK A.L., ECKERT S., SCHAIBLE T., SÜTTERLIN M., NEFF W. and SIEMER J.: Assessment of lung volume by 3 -dimensional sonography and magnetic resonance imaging in fetuses with congenital diaphragmatic hernias. J. Ultrasound Med., Nov., 30 (11): 153945, 2011.

7- TEUNE M.J., BAKHUIZEN S., GYAMFI BANNERMAN C., et al.: A systematic review of severe morbidity in infants born late preterm. American Journal of Obstetrics and Gynecology, 205: 374, e1-e9, 2011.

8- SENGUPTA S., CARRION V., SHELTON J., et al.: Adverse Neonatal Outcomes Associated with Early-Term Birth. JAMA Pediatr., 167: 1053-9, 2013.

9- WANG S.S., TIAN X.Y., YAN H.W., YUAN T., ZHENG X.Y. and HAN Z.: Prenatal assessment of pulmonary maturity on 3D ultrasound. Journal of Obstetrics and Gynaecology Research, Sep., 42 (9): 1086-93, 2016.

10- BESNARD A.E., WIRJOSOEKARTO S.A.M., BROEZE K.A., OPMEER B.C. and MOL B.W.J.: Lecithin/ sphingomyelin ratio and lamellar body count for fetal lung maturity: A meta-analysis. Eur. J. Obstet. Gynecol. Reprod. Biol., 169: 177-83, 2013.

11- LABAN M., MANSOUR G.M., ELSAFTY M.S., HASSANIN A.S. and EZZELARAB S. S.: Prediction of neonatal respiratory distress syndrome in term pregnancies by assessment of fetal lung volume and pulmonary artery resistance index. Int. J. Gynaecol. Obstet., Mar., 128 (3): 246-50, 2015

12- BAHMAIE A., HUGHES S.W., CLARK T., MILNER A., SAUNDERS J., TILLING K. and MAXWELL D.J.: Serial fetal lung volume measurement using three-dimensional ultrasound. Ultrasound Obstet. Gynecol., 16: 154-8, 2000.

13- POHLS U.G. and REMPEN A.: Fetal lung volumetry by threedimensional ultrasound. Ultrasound Obstet. Gynecol., 11: 6-12, 1998 .

14-LEE A., KRATOCHWIL A., STÜMPFLEN I., DEUTINGER J. and BERNASCHEK G.: Fetal lung volume determination by three-dimensional ultrasonography. Am. J. Obstet. Gynecol., 175: 588-92, 1996.

15- KALACHE K.D., ESPINOZA J., CHAIWORAPONGSA T., LONDONO J., SCHOEN M.L., TREADWELL M.C., LEE W. and ROMERO R.: Three-dimensional ultrasound 
fetal lung volume measurement: A systematic study comparing the multiplanar method with the rotational (VOCAL) technique. Ultrasound Obstet. Gynecol., 21: 1118, 2003.

16- PERALTA C.F., CAVORETTO P., CSAPO B., FALCON O. and NICOLAIDES K.H.: Lung and heart volumes by three-dimensional ultrasound in normal fetuses at 12-32 wk' gestation. Ultrasound Obstet. Gynecol., 27: 128-33, 2006.

17-KANTAKE M., YOSHITAKE H., ISHIKAWA H., ARAKI Y. and SHIMIZU T.: Postnatal epigenetic modification of glucocorticoid receptor gene in preterm infants: A prospective cohort study. BMJ Open, Jul. 14, 4 (7): e005318. doi: 10.1136/bmjopen-2014-005318. PMID: 25023132; PMCID: PMC4120337, 2014.

18- KHODAIR S., HASSANIEN O. and ELTOMEY M.: Three-dimensional Ultrasonography versus MRI in assessment of fetal Lung volumetric measurements; A Comparative study Type: Scientific Exhibit Authors. 10. 1594/ecr2014/C-03 66, 2014.

19- PRENDERGAST M., RAFFERTY G.F., DAVENPORT M., et al.: Three-dimensional ultrasound fetal lung volumes and infant respiratory outcome: A prospective observational study. BJOG, 118 (5): 608-14, 2011.

\section{دور الهوجات فوق الصوتية ثلاثية الآبعاد فى تقييه ريتى الجنين}

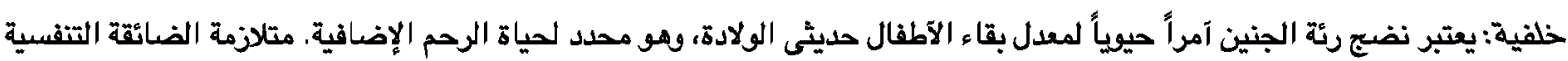

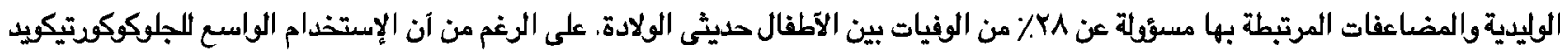

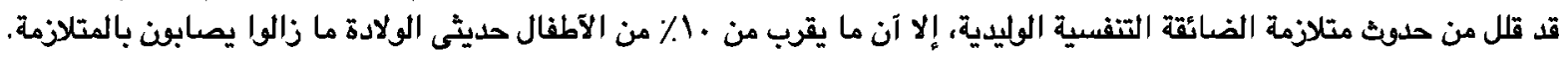

$$
\text { الهدف من البحث: دراسة دو الموجات فوق الصوتية ثلاثية الآبعاد فى تقييم رئتى الجنين. }
$$

المرضى وطرق البحث: تم تسجيل إجمالى • ه سيدة حامل ع ع-. ع إسبوعاً من الحمل بعد مسار الحمل الطبيعى الخالى من المضاعفات

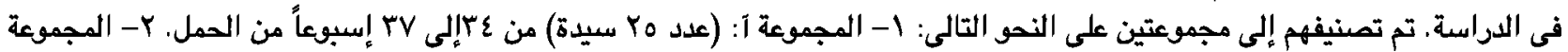

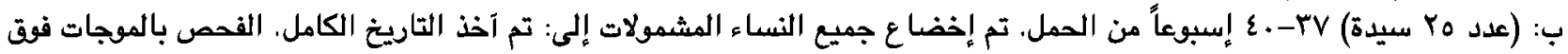

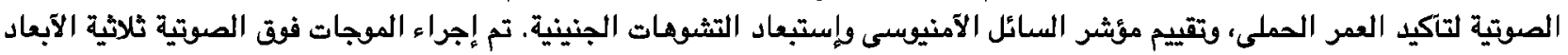
لتقدير حجم رئة الجنين. بعد ولادة الطفل، تم تقييم درجة APGAR عند (ا وه و. 1 دقائق) مع حلوث متئلازمة ضيق التنفس والحاجة الإضافية

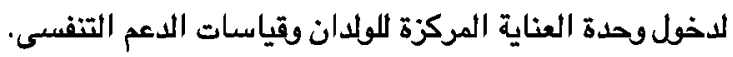

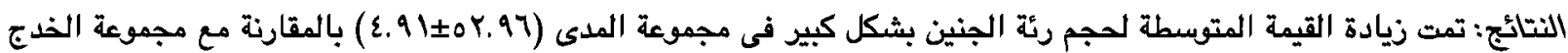

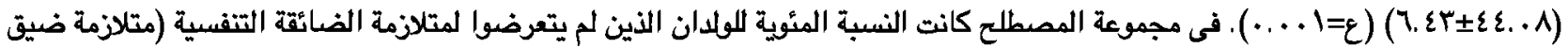

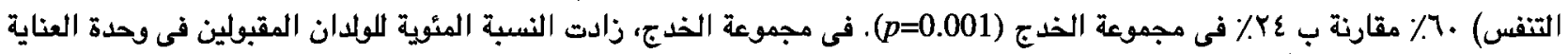

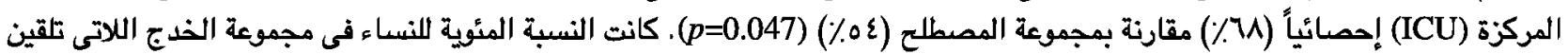

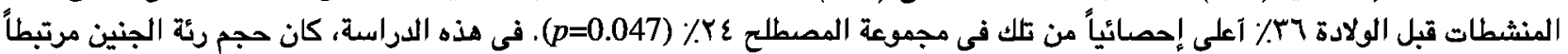

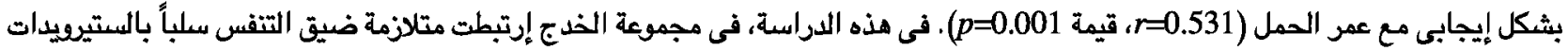

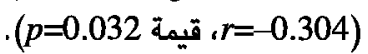

الخلاصة: مؤثرات الموجات فوق الصوتية، بما في ذلك حجم رئة الجنين قد تكن بمثابة بدائل مفيدة للفوبسفوليبيدات السائلة في تحليل

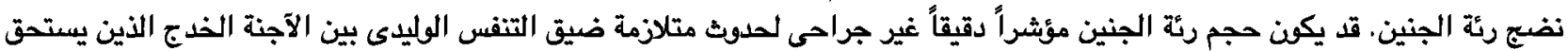
لديهم خطر الإصابة بمتلازمة ضيق التنفس إختبار نضبع رئة الجنين. 